\title{
Penerapan Teori Piaget dan Vygotsky Ruang Lingkup Bilangan dan Aljabar pada Siswa Mts Plus Karangwangi
}

\author{
Sumpena Rohaendi ${ }^{1, *}$, Nur Indah Laelasari ${ }^{2}$ \\ ${ }^{1,2}$ Universitas Subang \\ * sumpenarohaendi07786@gmail.com \\ \begin{tabular}{|l|l|l|} 
Received : 7-3-2020 & Revised: 9-4-2020 & Accepted: $9-4-2020$ \\
\hline
\end{tabular}
}

\begin{abstract}
ABSTRAK
Tujuan dari penelitian ini adalah untuk mengkaji lebih jauh tentang bagaimana penerapan teori Piaget dan Vygotsky ruang lingkup materi bilangan dan aljabar di MTs Plus Karangwangi. Metode penelitian yang digunakan dengan metode penelitian kualitatif. Alat yang digunakan dalam penelitian ini terdiri dari peneliti sebagai kunci utama. Sumber data yang digunakan adalah berupa buku, jurnal/artikel dan karya ilmiah lain yang relevan dengan objek kajian yang diteliti beserta siswa kelas VII MTs Plus Karangwangi. Adapun hasil dari penelitian ini yang berkaitan dengan teori Piaget yaitu, siswa membentuk kelompok-kelompok kecil yang beranggotakan $2-4$ orang tiap kelompok, sebelumnya diberi pengarahan pengajaran dari guru yang mendasar supaya anak berpikir dan memahami bilangan. Siswa sering di beri latihan berupa tugas pekerjaan rumah baik mandiri atau kelompok supaya lebih mengerti atau paham dengan baik. Dalam proses ini siswa akan belajar secara mandiri, sehingga siswa mampu untuk menguasai materi tanpa bimbingan seorang guru. Hal ini juga berfungsi untuk lebih mengasah interaksi sosial siswa, karena dalam hal ini siswa akan terpancing untuk menanyakan kepada orang lain tentang hal yang belum dipahaminya. Hasil penelitian ini yang berkaitan dengan teori Vygotsky yaitu pembelajaran dilakukan dengan ZPD dimana anak belajar kelompok kerja kreatif sehingga memudahkan untuk mengerti dengan cepat, dengan interaksi sosial dengan teman sebaya, anak mudah paham. Guru sebagai scaffolding dan guru mengurangi bantuannya itu sampai siswa bisa mandiri dan mengerti sendiri. Pembelajaran dengan tutor sebaya, siswa bisa tukar pikiran untuk memecahkan masalah yang kompleks sehingga menghasilkan atau dapat menarik kesimpulan dan menjadi pengetahuan.
\end{abstract}

Kata Kunci: Teori Piaget, Teori Vygotsky, Zone of proximal development (ZPD), Scaffolding

\section{ABSTRACT}

The aim of this research is to further examine how to the application of Piaget and Vygotsky's theories the scope of materials numbers and algebra on MTs Plus Karangwangi. The research method is used quantitative methods. The instrument is used in this research consisted of the researchers as the main key. The data source used form of book, journal or articles and other scientific works that are relevant to the object of the research VII grade students of MTs Plus Karangwangi. The result of the research is related to Piaget's theory, that is students form small group of 2-4 people per groups, previously given instruction from the teacher that is basic, so the students think and understand of numbers. The students often exercise of homework assignments either independent or in groups to better understand the material. The result of the research is related to Vygotsky's theory that learning is done with ZPD where students learn creative making groups it easier to understand quickly, with social interaction with peers, it easily understands. The teacher as scaffolding and teacher reduce until students can be independent and understand themselves. Learning with peer tutors, students can exchange ideas to solve complex problems as to procedure or be able to conclusions and knowledge. 
Keywords: Piaget theory, Vygotsky theory, Zone of proximal development (ZPD), Scaffolding

\section{PENDAHULUAN}

Psikologi belajar (teori belajar) adalah teori yang mempelajari perkembangan intelektual (mental) siswa. Di dalamnya terdiri atas dua hal yaitu: (a). menguraikan tentang apa yang terjadi dan diharapkan terjadi pada intelektual anak; (b). menguraikan tentang kegiatan intelektual anak mengenai hal-hal yang bisa dipikirkan pada usia tertentu. Pendapat ini sejalan dengan Trianto (2007) yang mengatakan bahwa, "teori belajar merupakan penjelasan bagaimana terjadinya belajar atau bagaimana informasi diproses di dalam pikiran siswa". Secara umum teori belajar dapat dikelompokkan menjadi empat aliran atau golongan, yaitu aliran tingkah laku, kognitif, humanistik, dan sibernetik. Aliran tingkah laku menekankan pada hasil dari proses belajar, aliran kognitif menekankan pada proses pembelajaran, aliran humanistik menekankan pada apa yang dipelajari, dan aliran sibernetik menekankan pada sistem informasi yang dipelajari.

Psikologi mengajar atau teori mengajar berisi tentang petunjuk bagaimana semestinya mengajar siswa pada usia tertentu, bila sudah siap belajar. Jadi pada teori mengajar terdapat prosedur dan tujuan mengajar. Pada pelaksanaannya kedua teori tersebut tidak bisa dipisahkan, seperti halnya kata belajar dan mengajar.

Dengan menguasai psikologi pembelajaran, guru bisa mengetahui kemampuan yang telah dimiliki siswa dan bagaimana proses berpikirnya. Disamping itu guru harus mengetahui pula tentang bagaimana menciptakan kegiatan pembelajaran sesuai dengan kondisi siswa dan tujuan pengajaran. Pendidikan yang berkualitas dapat ditingkatkan melalui melatih pemikiran menggunakan model pembelajaran yang tepat (Maskur et all, 2020).

Tall (2013) mengajukan skema teori belajar yang dikelompokkannya menjadi empat aliran yaitu behavioris, kognitif, konstruktivis, dan pendekatan sosial. Teori Piaget dan Vygotsky ditempatkannya pada aliran konstruktivis, namun pada skema tersebut digambarkan garis penghubung dengan aliran pendekatan sosial dan aliran kognitif. Aliran konstruktivis dipandangnya memiliki kesamaan dengan pendekatan sosial serta terkait dengan aliran kognitif. Teori Piaget dan Vygotsky memang menjadi cikal bakal berkembangnya konstruktivisme, namun Vygotsky memiliki perhatian lebih dalam hal pengaruh lingkungan sosial terhadap terbangunnya pengetahuan pada diri anak.

Perkembangan intelektual siswa berkaitan dengan psikologi kognitif dirinya sendiri, aliran yang berhubungan dengan psikologi kognitif di antaranya: teori menurut 
Piaget dan teori menurut Vygotsky. Teori Piaget menguraikan tentang perkembangan kognitif sebagian besar ditentukan oleh manipulasi dan interaksi aktif anak dengan lingkungan (Piaget, 2006), sedangkan teori Vygotsky lebih menenkankan pada aspek sosial dari pembelajaran. Menurut Vygotsky bahwa proses pembelajaran akan terjadi jika anak bekerja atau menangani tugas-tugas yang belum dipelajari, namun tugas-tugas tersebut masih berada dalam jangkauan mereka disebut dengan zone of proximal development dan disertai scaffolding (Daniels, 2016).

Sesuai dengan masalah yang dirumuskan, maka penulisan ini bertujuan untuk mengkaji lebih jauh tentang bagaimana penerapan teori Piaget dan Vygotsky dalam ruang lingkup materi bilangan dan aljabar di MTs Plus Karangwangi.

\section{Teori Piaget}

Istilah kognitif dapat diartikan sebagai salah satu domain atau wilayah/ranah psikologis manusia yang meliputi setiap perilaku mental yang berhubungan dengan pemahaman, pertimbangan, pengolahan informasi, pemecahan masalah, kesengajaan, dan keyakinan. Ranah psikologis ini menjadi penentu utama perilaku dan corak kehidupan manusia. Sesuai dengan pendapat Muhibbin (Juwantara, 2019) bahwa, ranah kejiwaaan yang berpusat di otak ini juga berhubungan dengan konasi (kehendak) dan afeksi (perasaan) yang bertalian dengan ranah rasa

Perkembangan kognitif sebagian besar ditentukan oleh manipulasi dan interaksi aktif anak dengan lingkungan. Piaget yakin bahwa pengalaman-pengalaman fisik dan manipulasi lingkungan penting bagi terjadinya perubahan perkembangan. Sementara itu bahwa interaksi sosial dengan teman sebaya, khususnya berargumentasi dan berdiskusi membantu memperjelas pemikiran yang pada akhirnya memuat pemikiran itu menjadi logis. Piaget memandang perkembangan kognitif sebagai suatu proses di mana anak secara aktif membangun sistem makna dan pemahaman realitas melalui pengalaman-pengalaman dan interaksi-interaksi (Nur (dalam Trianto, 2007)).

Kunci utama dari teori Piaget yang harus diketahui oleh guru yaitu kognitif seorang siswa bergantung kepada seberapa jauh siswa dapat memanipulasi dan aktif berinteraksi dengan lingkungannya. Pendapat ini sejalan dengan yang dikemukakan oleh Shadiq dan Mustajab (2011), perkembangan kognitif seorang siswa bergantung kepada seberapa jauh siswa itu dapat memanipulasi dan aktif berinteraksi dengan lingkungannya, dalam arti bagaimana ia mengaitkan antara pengetahuan yang telah dimiliki dengan pengalaman barunya. Menurut Piaget, ada tiga aspek pada perkembangan 
kognitif seseorang, yaitu: struktur, isi, dan fungsi kognitif. Struktur kognitif, skema atau skemata (schema) menurut Piaget, merupakan organisasi mental yang terbentuk pada saat seseorang berinteraksi dengan lingkungannya. Isi kognitif merupakan pola tingkah laku seseorang yang tercermin pada saat ia merespon berbagai masalah, sedangkan fungsi kognitif merupakan cara yang digunakan seseorang untuk mengembangkan tingkat intelektualnya, yang terdiri atas organisasi dan adaptasi.

Piaget (Illeris, 2004), semua skema apapun pada waktu yang sama adalah afektif dan kognitif. Piaget juga mengungkapkan bahwa kehidupan afektif seperti kehidupan kognitif, yaitu adaptasi berkelanjutan dan keduanya tidak hanya paralel tetapi interdependen, karena perasaan mengekspresikan minat dan memberikan nilai kepada tindakan serta kognitif yang menyediakan strukturnya.

Teori Piaget ini menekankan pada proses belajar terjadi menurut pola tahap-tahap perkembangan kognitif dari anak tersebut (disesuaikan dengan umur anak). Proses belajar menurut Piaget ini terdiri dari tiga tahapan, yakni asimilasi, akomodasi, dan equilibrasi. Dikatakan proses asimilasi jika ada pengintegrasian informasi baru ke struktur kognitif yang sudah ada di dalam benak siswa. Akomodasi yaitu penyesuaian struktur kognitif ke dalam situasi baru, sedangkan equilibrasi yaitu penyesuaian secara berkesinambungan antara asimilasi dan akomodasi. Sebagai contoh, seorang siswa yang sudah memahami perkalian, jika gurunya memperkenalkan tentang pembagian maka proses pengintegrasian antara perkalian yang sudah didapat dengan pembagian sebagai informasi baru, inilah yang dinamakan asimilasi. Jika siswa diberikan suatu permasalahan yang berkaitan dengan pembagian maka situasi ini dikatakan proses akomodasi. Agar siswa dapat terus berkembang dan menambah ilmunya sekaligus menjaga stabilitas mental dalam diri siswa tersebut diperlukan suatu proses penyeimbang (equilibrasi). Proses penyeimbang antara dunia luar dan dunia dalam, tanpa proses ini perkembangan kognitif siswa akan tersendatsendat.

Menurut Piaget, proses belajar harus disesuaikan dengan tahap perkembangan kognitif yang dilalui siswa. Tahap perkembangan kognitif yang dikemukakan oleh Piaget (Trianto, 2007) yaitu: tahap sensorimotor (dari lahir sampai usia 2 tahun), tahap praoperasional (usia 2 sampai 7 tahun), tahap operasi kongkrit (usia 7 sampai 11 tahun), dan tahap operasi formal (usia 11 sampai dewasa).

Proses belajar yang dialami oleh anak/siswa pada tahap sensorimotor tentu lain dengan yang dialami oleh anak yang sudah mencapai tahap praoperasional, dan lain lagi 
yang dialami pada anak pada tahap operasi kongkrit maupun operasi formal. Secara umum, semakin tinggi tingkat kognitif anak maka akan semakin abstrak cara berpikir anak tersebut. Maka dari itu, guru seharusnya memahami tahap-tahap perkembangan kognitif anak didik serta memberikan materi pelajaran dalam jumlah dan jenis yang sesuai dengan tahap-tahap perkembangan kognitif.

\section{Implikasi Teori Piaget dalam pendidikan}

Secara umum, pengaplikasian Teori Piaget adalah sebagai berikut: (a). Menentukan tujuan pembelajaran. (b). Memilih materi pelajaran. (c). Menentukan topik-topik yang mungkin dipelajari secara aktif oleh siswa. (d). Menentukan dan merancang kegiatan belajar yang cocok untuk topik-topik yang akan dipelajari misalnya kegiatan belajar dalam bentuk membentuk kelompok, role play, eksperimen, problem solving. (e). Mempersiapkan berbagai pertanyaan yang dapat memacu kreativitas siswa untuk berdiskusi atau bertanya. (f). Mengevaluasi proses dan hasil belajar.

Terdapat pokok-pokok pikiran yang dapat mewarnai "setting" pendidikan, yaitu pendekatan terpusat pada anak, akivitas, belajar secara individual, interaksi sosial. Pokokpokok pikiran Piaget dapat dipraktikkan dalam proses pembelajaran di kelas khususnya di SMP/MTs yaitu diantarannya.

a. Pembelajaran menggunakan metode student centered, yaitu dengan membuat kelompok-kelompok kecil dalam kelas atau dapat juga menggunakan sistem pembelajaran cooperative learning, kelompok-kelompok kecil akan melakukan diskusi tentang materi pembelajaran yang akan dibahas. Disini guru hanya berperan sebagai fasilitator yang bertugas memberikan pengarahan dan pengamatan pada saat diskusi berlangsung (Dimyati dan Mudjiono, 2010). Sehingga tampak proses pembelajaran ini merupakan proses pendekatan yang terpusat pada anak.

b. Dengan memberikan pertanyaan-pertanyaan dalam bentuk tes untuk membiasakan memberikan jenis-jenis pertanyaan yang memungkinkan untuk terlatihnya proses kognitif, misalnya dengan membiasakan memberikan pertanyaan "mengapa" terhadap suatu pertanyaan yang telah dikemukakan siswa sehingga dengan cara seperti ini seorang guru dapat mengecek sudah sampai dimana kematangan berfikirnya dan hasilnya bisa dijadikan umpan balik untuk perbaikan strategi interaksi yang lebih efektif. Dengan demikian seorang siswa juga dipaksa untuk melakukan aktivitas berfikir sehingga nantinya akan tertanam konsep yang sangat jelas di pikiran siswa tersebut. 
c. Pada akhir pembelajaran sebagai tindak lanjut ke pembelajaran berikutnya, siswa dibekali dengan tugas pekerjaan rumah. Baik itu pekerjaan rumah yang dilakukan secara individual maupun kelompok. Dalam proses ini siswa akan belajar secara mandiri, sehingga siswa mampu untuk menguasai materi tanpa bimbingan seorang guru. Hal ini juga berfungsi untuk lebih mengasah interaksi sosial siswa, karena dalam hal ini siswa akan terpancing untuk menanyakan kepada orang lain tentang hal yang belum dipahaminya.

\section{Teori Vygotsky}

Teori Vygotsky lebih menenkankan pada aspek sosial dari proses pembelajaran. Menurut Vygotsky bahwa proses pembelajaran akan terjadi jika anak bekerja atau menangani tugas-tugas yang belum dipelajari, namun tugas-tugas tersebut masih berada dalam jangkauan mereka disebut dengan zone of proximal development, yakni daerah tingkat perkembangan sedikit di atas daerah perkembangan seseorang saat ini (Trianto , 2007).

Tingkat perkembangan seseorang saat ini tidak lain adalah tingkat pengetahuan awal atau pengetahuan prasyarat itu telah dikuasai, maka kemungkinan sekali akan terjadi pembelajaran bermakna. Zona perkembangan proksimal yaitu rangkaian tugas yang terlalu sulit dikuasai anak seorang diri tetapi dapat dipelajari dengan bantuan dan bimbingan orang dewasa atau anak-anak yang terlatih.

Tahap dari teori Vygotsky yang paling mendasar adalah scaffolding yakni pemberian bantuan kepada siswa melalui tahap-tahap pembelajaran dan mengurangi bantuan tersebut dan memberikan kesempatan kepada siswa untuk melanjutkan pengerjaannya (Anthis \& Adams, 2012). Bantuan yang diberikan guru dapat berupa petunjuk, peringatan, dorongan menguraikan masalah ke dalam bentuk lain yang memungkinkan siswa dapat mandiri. Peran guru dalam Teori Vygotsky adalah sebagai fasilitator dan pembimbing.

\section{Penerapan Teori Belajar Vygotsky dalam Interaksi Belajar Mengajar}

Penerapan teori belajar Vygotsky dalam interaksi belajar mengajar mungkin dapat dijabarkan sebagai berikut.

a. Walaupun anak tetap dilibatkan dalam pembelajaran aktif, guru harus secara aktif mendampingi setiap kegiatan anak-anak. Dalam istilah teoritis, ini berarti anak-anak 
bekerja dalam Zone of proximal development (ZPD) dan guru menyediakan scaffolding bagi anak selama melalui ZPD.

b. Secara khusus Vygotsky mengemukakan bahwa disamping guru, teman sebaya juga berpengaruh penting pada perkembangan kognitif anak, kerja kelompok secara kooperatif tampaknya mempercepat perkembangan anak.

c. Gagasan tentang kelompok kerja kreatif ini diperluas menjadi pengajaran pribadi oleh teman sebaya (peer tutoring), yaitu seorang anak mengajari anak lainnya yang agak tertinggal dalam pelajaran. Satu anak bisa lebih efektif membimbing anak lainnya melewati ZPD karena mereka sendiri baru saja melewati tahap itu sehingga bisa dengan mudah melihat kesulitan-kesulitan yang dihadapi anak lain dan menyediakan scaffolding yang sesuai.

Pada dasarnya pokok-pokok pikiran yang dikemukakan Piaget dan Vygotsky tersebut sangat bagus jika diterapkan dalam pendidikan. Dari kedua teori tersebut maka mendapatkan persamaan dan perbedaan dalam teori Piaget dan Vygotsky jika diterapkan dalam proses belajar mengajar di SMP/MTs.

\section{Persamaan Teori Piaget dan Vygotsky.}

a. Sama-sama mementingkan anak yang berperan dalam proses belajar sedangkan guru sebagai fasilitator.

b. Walaupun mementingkan anak yang berperan tetapi secara teoritis guru juga harus memahami proses yang digunakan anak sehingga sampai pada jawaban tersebut.

\section{Perbedaan Teori Piaget dan Vygotsky}

\section{Teori Piaget}

Pembelajaran menggunakan metode student centered, yaitu dengan membuat kelompok-kelompok kecil dalam kelas atau dapat juga menggunakan sistem pembelajaran cooperative learning, kelompok-kelompok kecil akan melakukan diskusi tentang materi pembelajaran yang akan dibahas. Disini guru hanya berperan sebagai fasilitator yang bertugas memberikan pengarahan dan pengamatan pada saat diskusi berlangsung.

\section{Teori Vygotsky}

Gagasan tentang kelompok kerja kreatif diperluas menjadi pengajaran pribadi oleh teman sebaya (peer tutoring), yaitu seorang anak mengajari anak lainnya yang agak tertinggal dalam pelajaran. Satu anak bisa lebih efektif membimbing anak lainnya melewati ZPD karena mereka sendiri baru saja melewati itu sehingga bisa dengan mudah 
melihat kesulitan-kesulitan yang dihadapi anak lain dan menyediakan scaffolding yang sesuai.

Dengan dasar tersebut, maka dapat diambil kesimpulan bahwa proses belajar mengajar di SMP sebenarnya menggunakan kedua teori tersebut, namun lebih mengarah ke teori Vygotsky. Dengan alasan bahwa dalam proses belajar mengajar setelah pengajaran atau pemaparan materi sedikit terus dikasih tugas dan didiskusikan dengan temannya lalu hasil diskusinya dipresentasikan ke depan. Dalam proses ini menerapkan teori scaffolding yaitu memberikan sejumlah besar dukungan kepada anak selama tahap-tahap awal pembelajaran dan kemudian mengurangi bantuan dan memberikan kesempatan kepada anak itu untuk mengambil tanggung jawab yang semakin besar segera setelah anak mampu melakukannya. Menurut Vygotsky bahwa proses pembelajaran akan terjadi jika anak bekerja atau menangani tugas-tugas yang belum dipelajari, namun tugas-tugas tersebut masih berada dalam jangkauan siswa yang disebut disebut dengan zone of proximal development. Sebagian ada pula yang mengarah ke Piaget dimana siswa diberi tugas pekerjaan rumah. Baik itu pekerjaan rumah yang dilakukan secara individual maupun kelompok. Dalam proses ini siswa akan belajar secara mandiri, sehingga siswa mampu untuk menguasai materi tanpa bimbingan seorang guru. Hal ini juga berfungsi untuk lebih mengasah interaksi sosial siswa, karena dalam hal ini siswa akan terpancing untuk menanyakan kepada orang lain tentang hal yang belum dipahaminya.

\section{METODE PENELITIAN}

Metode penelitian yang digunakan adalah dengan metode penelitian kualitatif. Alat yang digunakan dalam penelitian ini terdiri dari peneliti sebagai kunci utama. Sebagaimana yang dikemukakan oleh (Sugiyono, 2016) bahwa, metode penelitian kualitatif adalah penelitian yang digunakan untuk meneliti pada kondisi obyek yang alamiah dimana peneliti adalah sebagai instrumen kunci. Sumber data yang digunakan adalah berupa buku, jurnal/artikel dan karya ilmiah lain yang relevan dengan objek kajian yang diteliti. Adapun populasi dan sampel adalah siswa MTs Plus Karangwangi kelas VII. Pokok bahasan dalam penelitian ini yaitu teori-teori Piaget dan Vygotsky dalam ruang lingkup Bilangan dan Aljabar.

Teknik pengumpulan data dalam penelitian ini meliputi: Observasi, studi kepustakaan, dan triangulasi. Langkah dalam penelitian ini mengacu pada pendapat Bogdan (Barsowi dan Suwandi, 2008: 84) yaitu dengan menyajikan tiga tahapan yaitu pralapangan, tahap kegiatan lapangan, dan tahap analisis data. 


\section{HASIL DAN PEMBAHASAN}

Menurut Tinggih (dalam Tim MKPBM, 2001) matematika adalah ilmu pengetahuan yang diperoleh dengan bernalar. Hal ini dimaksudkan bukan berarti ilmu lain diperoleh tidak melalui penalaran, akan tetapi dalam matematika lebih menekankan aktivitas dunia rasio (penalaran), sedangkan dalam ilmu lain lebih menekankan hasil observasi atau eksperimen di samping penalaran.

Menurut Piaget, terdapat pokok-pokok pikiran yang dapat mewarnai "setting" pendidikan, yaitu pendekatan terpusat pada anak, akivitas, belajar secara individual, interaksi sosial.

1. Pendekatan terpusat pada anak. Pada hakekatnya jalan pikiran anak terhadap realitas maupun cara pandangnya terhadap dunia sekitar. Guru harus menyadari dan mengobservasi anak dengan cermat untuk menemukan perspektifnya yang unik. Jadi yang penting adalah sensitifitas guru

2. Aktivitas, bahwa individu berapapun umurnya proses belajar yang paling baik didapatkan dari aktivitas yang merupakan inisiatif sendiri, sangat penting implikasinya di bidang pendidikan. Piaget selalu menekankan perlunya aktivitas tersebut baik fisik maupun mental. Mengetahui suatu objek adalah dengan melakukan sesuatu pada objek tersebut. Tugas guru adalah mendorong aktivitas anak didiknya, mengarahkan anak pada pengetahuan yang lebih mendalam dan tahan lama daripada sekedar ingatan terhadap fakta-fakta yang informasikan oleh guru atau dari buku-buku teks.

3. Belajar secara individual. Struktur kognisi anak yang berinteraksi dengan pengalaman baru menimbulkan minat dan menstimulir perkembangan kognisi yang lebih lanjut. Minat belajar akan dimudahkan oleh adanya pengalaman baru yang selain relevan dengan struktur kognisi yang telah dimilikinya, juga cukup berbeda sehingga menimbulkan konflik pada anak. Oleh karena pada usia yang sama struktur kognisi anak mungkin berbeda, hal yang menarik bagi mereka pun tidaklah sama. Murid membutuhkan guru yang sensitif terhadap kebutuhan kognisinya.

4. Interaksi sosial. Faktor lain yang mempengaruhi perkembangan adalah pengalaman sosial, atau interaksi dengan orang lain, memang mula-mula pikiran anak egosentris dalam arti anak memandang orang lain, objek atau kejadian sekitarnya dalam kaitannya dengan diri sendiri. Maka untuk mengurangi egosentrisme adalah interaksi sosial. sehingga mempunyai kepekaan terhadap lingkungan sekitar. Peranan interaksi sosial di sekolah perlu di bina. Murid-murid perlu bertukar pengalaman, memberikan alasan dan 
mempertahankan pendapatnya, semua itu akan merupakan cara yang penting untuk memperoleh pengetahuan.

Menurut Vygotsky, siswa perlu dibiasakan untuk memecahkan masalah, menemukan sesuatu yang berguna bagi dirinya, dan bergelut dengan ide-ide. Guru tidak akan mampu memberikan semua pengetahuan kepada siswa. Siswa harus mengkontruksikan pengetahuan di benak mereka sendiri. Dalam proses pembelajaran, siswa harus membangun sendiri pengetahuan mereka melalui keterlibatan aktif dalam proses belajar mengajar. Siswa menjadi pusat kegiatan, bukan guru.

Sehubungan dengan paparan di atas mengenai Teori dari Piaget dan Vygotsky yang berkenaan dengan pembelajaran terutama matematika dalam ruang lingkup materi bilangan dan aljabar di MTs Plus Karangwangi adalah sebagai berikut.

\section{Berdasarkan Teori Piaget}

Pembelajaran matematika SMP/MTs yang paling awal dan mendasar yaitu tentang materi bilangan. Agar siswa memahami suatu bilangan, kita gunakan tahap-tahap pokok pikiran Piaget yakni: berpusat pada anak, akivitas, belajar secara individual, interaksi sosial. Siswa membentuk kelompok-kelompok kecil yang beranggotakan $2-4$ orang tiap kelompok, sebelumnya diberi pengarahan pengajaran dari guru yang mendasar supaya anak berpikir dan memahami bilangan. Siswa sering di beri latihan berupa tugas pekerjaan rumah baik mandiri atau kelompok supaya lebih mengerti atau paham dengan baik. Dalam proses ini siswa akan belajar secara mandiri, sehingga siswa mampu untuk menguasai materi tanpa bimbingan seorang guru. Hal ini juga berfungsi untuk lebih mengasah interaksi sosial siswa, karena dalam hal ini siswa akan terpancing untuk menanyakan kepada orang lain tentang hal yang belum dipahamiya. Untuk materi aljabar, proses pengajarannya sama dengan materi pada bilangan yaitu pembentukan kelompok-kelompok kecil.

\section{Berdasarkan Teori Vygotsky}

a. Pembelajaran bilangan dilakukan dengan ZPD dimana anak belajar kelompok kerja kreatif sehingga memudahkan dia untuk mengerti dengan cepat, dengan interaksi sosial dengan teman sebaya, anak mudah paham. Guru sebagai scaffolding dan guru mengurangi bantuannya itu sampai siswa bisa mandiri dan mengerti sendiri. Pembelajaran dengan tutor sebaya, siswa bisa tukar pikiran untuk memecahkan masalah yang kompleks tentang bilangan sehingga menghasilkan atau dapat menarik kesimpulan dan menjadi pengetahuan. 
b. Aljabar juga dilakukan dengan ZPD supaya mudah untuk memahaminya dimana siswa berkelompok kerja kreatif (teman sebaya) mengelompokan benda, bentuk atau hal lain yang sejenis atau tidak sejenis (untuk operasi aljabar) dan guru sebagai scaffolding kemudian mengurangi bantuannya sampai siswa mandiri atau mengerti dengan sendirinya. Dengan ZPD maka akan dapat memecahkan masalah yang kompleks yang memerlukan interaksi sosial sehingga dapat menarik kesimpulan dari hasil diskusi dengan bimbingan guru sebagai fasilitator agar tidak terjadi salah penafsiran.

\section{KESIMPULAN}

Berdasarkan hasil penelitian dan pembahasan diperoleh kesimpulan berkaitan dengan Teori dari Piaget dan Vygotsky yang berkenaan dengan pembelajaran matematika terutama dalam ruang lingkup materi bilangan dan aljabar di MTs Plus Karangwangi adalah dengan membentuk kelompok-kelompok kecil yang beranggotakan $2-4$ orang tiap kelompok, sebelumnya diberi pengarahan pengajaran dari guru yang mendasar supaya anak berpikir dan memahami bilangan. Siswa sering di beri latihan berupa tugas pekerjaan rumah baik mandiri atau kelompok supaya lebih mengerti atau paham dengan baik. Dalam proses ini siswa akan belajar secara mandiri, sehingga siswa mampu untuk menguasai materi tanpa bimbingan seorang guru. Hal ini juga berfungsi untuk lebih mengasah interaksi sosial siswa, karena dalam hal ini siswa akan terpancing untuk menanyakan kepada orang lain tentang hal yang belum dipahaminya. Hasil penelitian ini yang berkaitan dengan teori Vygotsky yaitu pembelajaran dilakukan dengan ZPD dimana anak belajar kelompok kerja kreatif sehingga memudahkan untuk mengerti dengan cepat, dengan interaksi sosial dengan teman sebaya, anak mudah paham. Guru sebagai scaffolding dan guru mengurangi bantuannya itu sampai siswa bisa mandiri dan mengerti sendiri. Pembelajaran dengan tutor sebaya, siswa bisa tukar pikiran untuk memecahkan masalah yang kompleks sehingga menghasilkan atau dapat menarik kesimpulan dan menjadi pengetahuan. 


\section{REFERENSI}

Anthis, K., \& Adams, L. (2012). Scaffolding. Teaching of Psychology, 39(4), 284-287. https://doi.org/10.1177/0098628312456629

Barsowi \& Suwandi. (2008). Memahami Penelitian Kualitatif. Jakarta: Rineka Cipta.

Daniels, H. (2016). Vygotsky and Pedagogy. In Vygotsky and Pedagogy. https://doi.org/10.4324/9781315617602

Dimyati dan Mudjiono(2010:200). (2010). Model-model pengajaran dan pembelajaran. Teaching and Educations, 1, 272

Illeris, K. (2004). The three dimensions of learning. Florida: Krieger Publishing.

Juwantara, R.A. (2019). Analisis Teori Perkembangan Kognitif Piaget pada Tahap Anak Usia Operasional Kongkret 7-12 Tahun dalam Pembelajaran Matematika. Jurnal Ilmiah Pendidikan Guru Madrasah Ibtidaiyah, Volume 9 No 1 (Juni 2019), hal 27-34.

Maskur, R., Sumarno, S., Rahmawati, Y., Pradana, K., Syazali, M., Septian, A., \& Kinarya Palupi, E. (2020). The effectiveness of problem based learning and aptitude treatment interaction in improving mathematical creative thinking skills on Curriculum 2013. European Journal of Educational Research, 9(1), 375-383. https://doi.org/10.12973/eujer.9.1.375.

Piaget, J. (2006). Jean Piaget. In A History of Psychology in Autobiography, Vol IV. (pp. 237-256). https://doi.org/10.1037/11154-011

Shadiq, F \& Mustajab, N.A (2011). Penerapan Teori Belajar dalam Pembelajaran Matematika di SD. Kementerian Pendidikan Nasional Badan Pengembangan Sumber Daya Manusia Pendidikan dan Penjaminan Mutu Pendidikan, Pusat Pengembangan dan Pemberdayaan Pendidik dan Tenaga Kependidikan Matematika Yogyakarta.

Sugiyono, S. (2016). Memahami Penelitian Kualitatif, Cet. Ke-12. Bandung: Alfabeta.

Tall, D. (2013). Integrating History, Technology and Education in Mathematics. Paper presented at História e Tecnologia no Ensino da Matemática July 15, Universidade Federal de São Carlos, Brazil.

Tim MKPBM. (2001).Strategi Pembelajaran Matematika Kontemporer.Bandung: Jurusan Pendidikan Matematika, Fakultas Pendidikan Matematika dan Ilmu Pengetahuan Alam. Universitas Pendidikan Indonesia.

Trianto. (2007). Model-model Pembelajaran Inovatif Berorientasi Konstruktivistik Jakarta:Prestasi Pustaka Publisher. 